\title{
SEX RATIO ANAK PUYUH (Coturnix-coturnix japonica) PADA TETUA YANG DIBERI RANSUM TERSUPLEMENTASI MINERAL Zn DAN VITAMIN E
}

\author{
Rahmawati Rachim ${ }^{1}$ \\ ${ }^{1)}$ Alumnus Fakultas Peternakan UHO \\ e-mail: rahma_rachim@yahoo.com
}

\begin{abstract}
Abstrak
Jenis kelamin unggas dapat dimanipulasi, yaitu melalui pengubahan jumlah hormon estrogen dan testosteron di dalam tubuh dan yolk. Pengubahan ini dapat dilakukan melalui pengaturan kandungan $\mathrm{Zn}$ pada pakan. Selain $\mathrm{Zn}$ yang dapat mempengaruhi fungsi reproduksi ternak, vitamin E juga bermanfaat untuk meningkatkan fertilitas, pertumbuhan embrio normal dan sebagai antioksidan. Penelitian bertujuan untuk mengkaji pengaruh suplemen mineral Zn, vitamin E dan interaksi keduanya terhadap sex ratio anak puyuh. Penelitian menggunakan Rancangan Acak Lengkap (RAL) pola faktorial 3 x 3 dengan 3 ulangan. Faktor pertama adalah level mineral $\mathrm{Zn}(0 \mathrm{mg}$, 50mg dan 100mg) ) dan faktor kedua adalah level vitamin E (0ppm, 45ppm dan 50ppm). Setiap unit percobaan terdiri dari 2 ekor puyuh betina dan 1 ekor puyuh jantan. Parameter yang diukur adalah konsumsi ransum, bobot telur, daya tetas dan sex ratio anak puyuh. Hasil penelitian menunjukkan bahwa Interaksi antara mineral Zn dan vitamin E berpengaruh terhadap bobot telur, namun tidak berpengaruh terhadap konsumsi ransum, daya tetas dan sex ratio anak puyuh. Penambahan mineral $\mathrm{Zn}$ berpengaruh nyata terhadap bobot telur, namun tidak mempengaruhi konsumsi ransum, daya tetas dan sex ratio anak puyuh. Penambahan vitamin E berpengaruh nyata terhadap konsumsi ransum, bobot telur dan daya tetas, namun tidak berpengaruh terhadap sex ratio anak puyuh.
\end{abstract}

Kata kunci : Anak puyuh, mineral Zn, vitamin E, sex ratio.

\begin{abstract}
Poultry sex could be manipulated by changing the amount of estrogen and testosterone in the poultry body and it's yolk. This changing could be done by managing the $\mathrm{Zn}$ level in feed. Beside $\mathrm{Zn}$, vitamin $\mathrm{E}$ also could affect the reproduction in animal by increasing fertility, embrio growth, and acting as an atioxidant. This study was aimed to evaluate the effect of $\mathrm{Zn}$ supplement, vitamin $\mathrm{E}$ and their interaction on day old quail. This study using $3 \times 3$ factorial based on completely randomized design with 3 replications. The first factor was $\mathrm{Zn}$ level (0 , 50 and 100 $\mathrm{mg})$, and the second factor was vitamin E level (0, 45, and $50 \mathrm{ppm})$. Each research unit consist of 1 male and 2 female quails. The measured parameters were feed consumption, egg weight, hatchtability, and its day old quail sex. The result of this study showed that interaction between $\mathrm{Zn}$ and vitamin E level affect egg weight. In the contrary, interaction between $\mathrm{Zn}$ and vitamin $\mathrm{E}$ evel did not affect the feed consumption, hacthability, and sex ratio of day old quail. The addition of vitamin E gave a signifficant effect on feed consumption, egg weight, and hatchability, but did not give any signifficant effect on sex ratio of day old quail.
\end{abstract}

Keywords: Day old quail, Zn mineral, vitamin E, sex ratio. 


\section{PENDAHULUAN}

\section{Latar Belakang}

Burung puyuh (Coturnix coturnix japonica) umumnya dipelihara untuk diambil telurnya. Namun saat ini sudah mulai berkembang usaha untuk memasarkan daging puyuh yang awalnya hanya diperoleh dari puyuh petelur afkir. Daging puyuh mulai digemari masyarakat, karena selain rasanya yang lebih enak dan gurih, kadar lemak daging puyuh lebih rendah dibanding daging ayam (boiler), sehingga prospek usaha ternak puyuh pedaging cukup menjanjikan. Puyuh yang berpotensi dikembangkan sebagai penghasil daging adalah puyuh jantan.

Salah satu kendala saat ini adalah sulitnya memperoleh bibit jantan yang relatif seragam, sehingga perlu adanya pengaturan jenis kelamin yang dapat menghasilkan bibit puyuh jantan yang memadai baik dari segi kualitas maupun kuantitasnya. Jenis kelamin unggas dapat dimanipulasi, yaitu melalui pengubahan jumlah hormon estrogen dan testosteron di dalam tubuh dan yolk. Pengubahan ini dapat dilakukan melalui pengaturan kandungan Zn pada pakan (Hamzah dkk, 2009).Mineral $\mathrm{Zn}$ diketahui dapat menghambat kerja enzim aromatase (aromatase inhibitor) yang berfungsi mengubah testosteron menjadi estrogen. Aromatase adalah enzim yang mengkatalis reaksi androgen menjadi estrogen (Vaillant et al., 2001). Reaksi ini terjadi pada semua makhluk hidup tingkat tinggi pada fase-fase tertentu yang akan mengarahkan penentuan kelamin dari makhluk hidup tersebut. Jenis kelamin suatu individu sudah ditetapkan pada saat pembuahan, namun pada masa embrio, gonad masih dalam keadaan indiferen yaitu keadaan dimana struktur betina dan jantan sudah ada. Pada fase pertumbuhan gonad, perubahan jenis kelamin dapat diarahkan dengan pemberian mineral $\mathrm{Zn}$ sebagai arometase inhibitor.

Selain $\mathrm{Zn}$ yang dapat mempengaruhi fungsi reproduksi ternak, vitamin $E$ juga bermanfaat untuk meningkatkan fertilitas, pertumbuhan embrio normal dan sebagai antioksidan. Menurut Dian dkk, (2009) vitamin E merupakan salah satu vitamin yang larut dalam lemak yang melindungi tubuh dari radikal bebas. Radikal bebas dapat merusak integritas DNA pada nukleus spermatozoa, sehingga menyebabkan turunnya kualitas spermatozoa. Kualitas spermatozoa erat kaitannya dengan fertilitas, karena dengan spermatozoa yang berkualitas, proses pembuahan sel telur dapat berjalan dengan baik.

Berdasarkan uraian diatas, maka dianggap perlu untuk melakukan penelitian tentang sex ratio anak puyuh pada tetua yang diberi ransum tersuplementasi mineral $\mathrm{Zn}$ dan vitamin $\mathrm{E}$.

\section{METODOLOGI PENELITIAN}

Penelitian ini dilaksanakan di Kandang Kelompok Peternak Puyuh "Permata" Kota Kendari. Burung puyuh Fase Layer ( \pm 10 minggu) sebanyak 81 ekor, ditempatkan dalam petak kandang yang berukuran $40 \times 30 \times 20 \mathrm{~cm} /$ unit yang telah disekat sejumlah 27 unit percobaan.

Pakan yang digunakan merupakan konsentrat yang diberi suplemen mineral $\mathrm{Zn}$ berupa $\mathrm{ZnSO} 4.7 \mathrm{H} 2 \mathrm{O}$ dan vitamin $\mathrm{E}$ dalam bentuk DL-Alpha Tocopherol Acetate sesuai perlakukan. Komposisi kimia konsentrat yang digunakan dapat dilihat pada Tabel 2. Penelitian disusun berdasarkan Rancangan Acak Lengkap (RAL) pola faktorial $3 \times 3$ dengan 3 ulangan. Faktor pertama adalah level mineral $\mathrm{Zn}$ yang terdiri dari $0 \mathrm{mg}, 50 \mathrm{mg}$ dan $100 \mathrm{mg}$. Faktor kedua adalah level 
vitamin E yang terdiri dari : $0 \mathrm{ppm}, 45$ ppm dan $50 \mathrm{ppm}$

Peralatan yang digunakan antara lain : mesin tetas manual kapasitas 100 butir telur puyuh dan timbangan merk Ohaus kapasitas maksimal $2 \mathrm{~kg}$ dan timbangan digital.

Tabel 2. Komposisi Kimia Ransum Basal

\begin{tabular}{ccccccc}
\hline Jenis Ransum & Air (\%) & Abu (\%) & $\begin{array}{c}\text { Protein } \\
\text { Kasar }(\%)\end{array}$ & $\begin{array}{c}\text { Lemak } \\
\text { Kasar }(\%)\end{array}$ & $\begin{array}{c}\text { Serat Kasar } \\
(\%)\end{array}$ & $\begin{array}{c}\text { Ca } \\
(\%)\end{array}$ \\
\hline $\begin{array}{c}\text { Ransum } \\
\text { Puyuh }\end{array}$ & 9,65 & 11,63 & 16,85 & 3,36 & 8,35 & 3,18 \\
\hline
\end{tabular}

Sumber : Hasil Analisis Balai Pengujian Mutu dan Sertifikasi Pakan, Ditjennak, 2014

Campuran pakan yang digunakan berupa konsentrat sebanyak 35\%, jagung giling $40 \%$ dan dedak $25 \%$. Mineral $\mathrm{Zn}$ dan vitamin E dicampur dalam pakan sesuai perlakukan. Pemberian pakan dilakukan 2 kali sehari, dan air minum secara ad libithum.

Sebelum digunakan kandang, peralatan dan mesin tetas dibersihkan dan disucihamakan. Kandang puyuh dibuat menjadi 27 petak sesuai dengan jumlah unit percobaan, setiap unit kandang ditempatkan secara acak 1 ekor puyuh jantan dan 2 ekor puyuh betina. Ransum perlakuan diberikan pada ternak puyuh umur \pm 10 minggu sampai umur 16 minggu. Setelah puyuh bertelur, telur dikumpulkan setiap hari.

Tiap 6 (enam) hari sekali telur yang telah terkumpul ditetaskan menggunakan mesin tetas kapasitas 100 butir. Lama penetasan berkisar antara 1617 hari. Pembalikan telur dilakukan minimal 3 kali sehari, dimulai pada hari ke-2 sampai hari ke-14. Penetasan dilakukan sebanyak 4 (empat) kali selama penelitian. Selanjutnya dilakukan sexing untuk mengetahui jenis kelamin puyuh berdasarkan warna bulu pada bagian dadanya. Sexing dilakukan pada saat puyuh berumur 3 minggu.

Parameter yang diamati adalah :
1. Konsumsi ransum

2. Bobot Telur (g)

3. Daya Tetas (\%)

4. Sex Ratio/ Jenis kelamin

Data yang terkumpul dianalisis dengan analisis ragam, dan beda antar perlakuan diuji dengan uji jarak berganda duncan (Hanafiah, 2008).

\section{HASIL DAN PEMBAHASAN}

\section{Konsumsi Ransum}

Konsumsi ransum dihitung dari jumlah ransum yang diberikan dikurangi dengan sisa ransum selama seminggu. Rataan konsumsi ransum puyuh yang tersuplementasi mineral $\mathrm{Zn}$ dan vitamin $\mathrm{E}$ selama penelitian tertera pada Tabel. 4 .

Hasil analisis ragam menunjukkan bahwa interaksi antara mineral seng (Zn) dan vitamin $\mathrm{E}$ tidak berpengaruh nyata $(\mathrm{P}<0.05)$ terhadap rataan konsumsi ransum puyuh. Demikian halnya dengan pengaruh tunggal perlakuan mineral seng dalam ransum belum mampu memberikan pengaruh nyata $(\mathrm{P}<0.05)$ terhadap rataan konsumsi ransum burung puyuh. Hal ini berarti pemberian mineral seng $0 \mathrm{mg}, 50$ $\mathrm{mg}$, dan $100 \mathrm{mg}$ belum mampu meningkatkan atau menurunkan konsumsi bahan kering ransum. Demikian halnya dengan 
Tabel 4. Rataan Konsumsi Ransum Puyuh yang Tersuplementasi Mineral Zn dan Vitamin $\mathrm{E}$ (g/ekor/minggu)

\begin{tabular}{lllll}
\hline Perlakuan Pakan & \multicolumn{3}{c}{ Vitamin (ppm) } & Rataan \\
\cline { 2 - 4 } & E0 (0) & E1 (45) & E2 (50) & \\
\hline M0 (Zn 0 mg) & 482 & 500 & 480 & 487 \\
M1 (Zn 50 mg) & 484 & 490 & 480 & 485 \\
M2 (Zn 100 mg) & 479 & 494 & 491 & 488 \\
\hline Rataan & $482^{\mathrm{b}}$ & $495^{\mathrm{a}}$ & $486^{\mathrm{b}}$ & \\
\hline
\end{tabular}

Superskrip yang berbeda pada baris atau kolom yang sama menunjukkan perbedaan nyata pada taraf $0.05(\mathrm{P}<0.05)$

pemberian mineral seng belum mampu mengubah palatabilitas pakan sehingga jumlah pakan yang dikonsumsi tidak berbeda. Penambahan mineral seng (Zn) sampai dosis $75 \mathrm{mg}$ dalam $1 \mathrm{~kg}$ ransum belum mampu meningkatkan laju pencernaan, sehingga laju digesta tidak berubah secara nyata. Hasil tersebut sesuai dengan pendapat Prihatinningsih (2014) bahwa penambahan seng (Zn) dalam ransum puyuh tidak mempengaruhi produksi telur, konsumsi ransum dan konversi ransum. Menurut Hamzah dkk. (2009) penggunaan Zn sampai level $75 \mathrm{mg} / \mathrm{kg}$ pakan tidak mempengaruhi konsumsi pakan.

Perlakuan tunggal vitamin $\mathrm{E}$ memberikan pengaruh yang nyata $(\mathrm{P}<0.05)$ terhadap rataan konsumsi puyuh. Hasil uji beda nyata antar perlakuan menunjukkan bahwa rataan konsumsi pakan perlakuan E1 (vitamin E $=45 \mathrm{ppm}$ ) nyata lebih tinggi dibandingkan dengan perlakuan E0 $($ vitamin $\mathrm{E}=0 \mathrm{ppm})$ dan $\mathrm{E} 2$ (vitamin $=$ 50ppm). Hasil tersebut menunjukkan bahwa vitamin $\mathrm{E}$ dapat mempengaruhi konsumsi pakan. Kondisi ini mungkin berkaitan dengan fungsi vitamin $\mathrm{E}$ yaitu mencegah stress, sehingga ternak dapat mengkonsumsi pakan dengan baik. Lubis (2012) menyatakan bahwa meningkatnya daya cerna akan mempercepat proses metabolisme nutrisi sehingga konsumsi ternak meningkat. Selanjutnya Surai (2003) berpendapat bahwa vitamin E berperan melindungi jaringan pancreas dari kerusakan oksidatif, sehingga pancreas dapat berfungsi dengan baik menghasilkan enzim-enzim pencernaan yang akan meningkatkan daya cerna nutrisi.

\section{Bobot Telur}

Data bobot telur diperoleh dari hasil penimbangan telur setiap butirnya. Rataan bobot telur puyuh yang diberi pakan tersuplementasi mineral $\mathrm{Zn}$ dan vitamin $\mathrm{E}$ dapat dilihat pada Tabel 5.

Hasil analisis ragam menunjukkan interaksi antara mineral seng $(\mathrm{Zn})$ dan vitamin $\mathrm{E}$ berpengaruh nyata $(\mathrm{P}<0.05)$ terhadap rataan bobot telur puyuh. Bobot telur yang dihasilkan berkisar antara 9.25 $\mathrm{g}-11.52 \mathrm{~g} /$ butir, dan masih merupakan bobot telur puyuh normal. Seperti dijelaskan Mahi dkk (2012) bahwa bobot telur tetas burung puyuh yang baik berkisar antara 9-10 gram. Meski demikian, bobot telur cenderung lebih tinggi pada puyuh yang mendapat suplemen mineral seng $(50 \mathrm{mg}-100 \mathrm{mg})$ dan vitamin $\mathrm{E}$ (45 ppm - 50ppm) berkisar antara $10.07 \mathrm{~g}-11.52 \mathrm{~g}$. 
Tabel 5. Rataan Bobot Telur Puyuh yang Tersuplementasi Mineral Zn dan Vitamin E (g/butir)

\begin{tabular}{lcccc}
\hline Perlakuan Pakan & \multicolumn{3}{c}{ Vitamin (ppm) } & Rataan \\
\cline { 2 - 4 } & E0 (0) & E1 (45) & E2 (50) & \\
\hline M0 (Zn 0 mg) & $10.55^{\mathrm{bc}}$ & $10.94^{\mathrm{ab}}$ & $10.17^{\mathrm{d}}$ & $10.55^{\mathrm{b}}$ \\
M1 (Zn 50 mg) & $9.25^{\mathrm{e}}$ & $10.07^{\mathrm{de}}$ & $11.34^{\mathrm{a}}$ & $10.31^{\mathrm{b}}$ \\
M2 (Zn 100 mg) & $11.05^{\mathrm{ab}}$ & $10.52^{\mathrm{bc}}$ & $11.52^{\mathrm{a}}$ & $10.96^{\mathrm{a}}$ \\
\hline Rataan & $10.39^{\mathrm{b}}$ & $10.51^{\mathrm{b}}$ & $10.94^{\mathrm{a}}$ & \\
\hline
\end{tabular}

Superskrip yang berbeda pada baris dan kolom yang sama menunjukkan perbedaan nyata pada taraf $0.05(\mathrm{P}<0.05)$

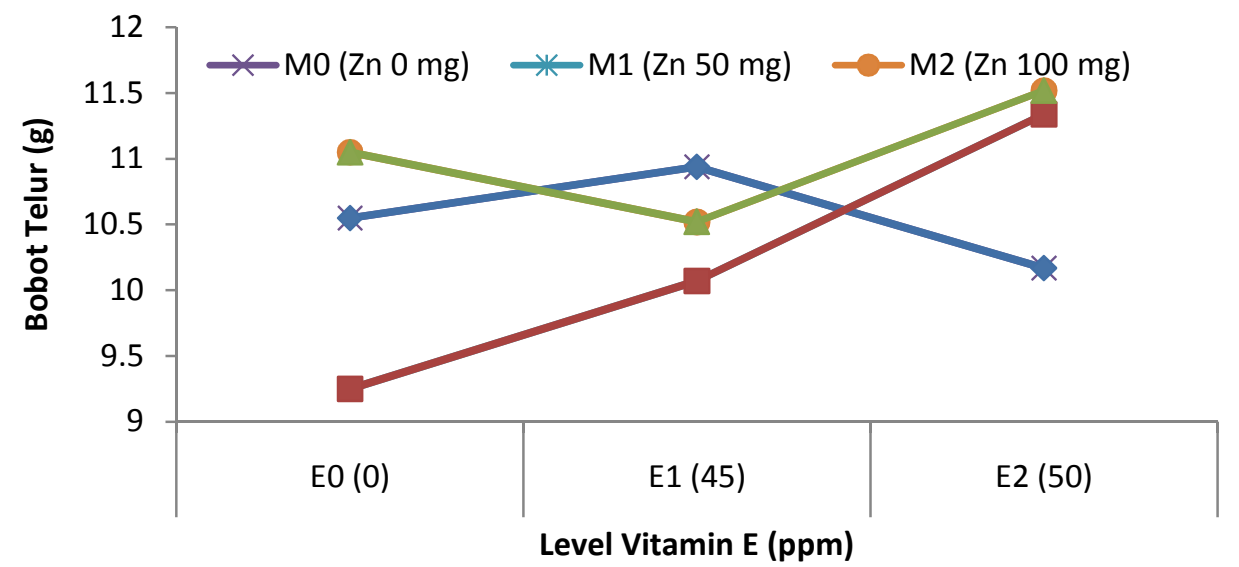

Gambar 2. Grafik rataan bobot telur puyuh yang tersuplementasi mineral Zn dan vitamin $\mathrm{E}$ (g/butir)

Bobot telur dapat dipengaruhi oleh beberapa hal salah satunya adalah kandungan nutrien ransum. Sestilawarti (2011) menyatakan bobot telur dipengaruhi oleh nutrien yang terkandung dalam ransum berupa protein dan lemak. Selanjutnya dikatakan bahwa kekurangan protein akan mengakibatkan menurunnya jumlah albumen telur, dan besar telur menjadi lebih kecil meskipun jumlah kuning telur tetap. Peningkatan bobot telur pada pemberian mineral $\mathrm{Zn}(50 \mathrm{mg}-$ $100 \mathrm{mg}$ ) dan vitamin E (45ppm - 50ppm) dapat dilihat pada Gambar 2.

Gambar 2 menunjukkan bahwa pemberian mineral $\mathrm{Zn}$ dan vitamin $\mathrm{E}$ secara bersamaan cenderung meningkatkan bobot telur. Peningkatan bobot telur tersebut disebabkan karena pemberian vitamin $\mathrm{E}$ dan mineral $\mathrm{Zn}$ secara bersamaan dapat meningkatkan kualitas telur. Peningkatan kualitas telur disebabkan peranan vitamin $\mathrm{E}$ yang mampu melindungi spermatozoa dari kerusakan akibat radikal bebas sedangkan mineral $\mathrm{Zn}$ akan mengaktifkan kerja enzim metabolisme yang menghasilkan energi yang dibutuhkan untuk pergerakan spermatozoa (Suharyati, 2006).

Hasil sidik ragam menunjukkan bahwa pemberian tunggal vitamin $\mathrm{E}$ dalam ransum berpengaruh nyata $(\mathrm{P}<0.05)$ terhadap bobot telur, hal ini berarti pengaruh pemberian vitamin $\mathrm{E}$ dengan dosis $0 \mathrm{mg} / \mathrm{kg}$ pakan, $45 \mathrm{mg} / \mathrm{kg}$ pakan, dan $50 \mathrm{mg} / \mathrm{kg}$ pakan dalam ransum dapat 
meningkatkan bobot telur puyuh. Hal ini disebabkan karena vitamin $\mathrm{E}$ memiliki fungsi penting dalam reproduksi dan perkembangan embrio, dimana dapat meningkatkan kematangan sperma pada pejantan dan meningkatkan kesuburan organ reproduksi pada betina. Selain itu vitamin $\mathrm{E}$ merupakan vitamin yang dibutuhkan oleh ternak yang berperan sebagai antioksidan, membantu dalam perkembangan embrio dan fertilitas ternak. Antioksidan mempunyai peran

Tabel 6. Rataan Daya Tetas Telur Puyuh yang Tersuplementasi Mineral Zn dan Vitamin $\mathrm{E}(\%)$

\begin{tabular}{lllll}
\hline Perlakuan Pakan & \multicolumn{3}{c}{ Vitamin $(\mathrm{ppm})$} & Rataan \\
\cline { 2 - 4 } & E0 (0) & E1 (45) & E2 (50) & \\
\hline M0 (Zn 0 mg) & 25 & 73 & 20 & 39 \\
M1 (Zn 50 mg) & 32 & 52 & 43 & 42 \\
M2 (Zn 100 mg) & 16 & 33 & 50 & 33 \\
\hline Rataan & $24^{\mathrm{b}}$ & $53^{\mathrm{a}}$ & $38^{\mathrm{ab}}$ & \\
\hline
\end{tabular}

Ket : Superskrip yang berbeda pada baris yang sama menunjukkan perbedaan nyata pada taraf $0.05(\mathrm{P}<0.05)$

asupan antioksidan yang cukup ke dalam tubuh ternak tersebut.

Demikian pula dengan pemberian tunggal mineral seng $(\mathrm{Zn})$, hasil sidik ragam menunjukkan bahwa pemberian mineral seng $(\mathrm{Zn})$ dalam ransum berpengaruh nyata $(\mathrm{P}<0.05)$ terhadap bobot telur. Mineral $\mathrm{Zn}$ mempunyai berbagai fungsi di dalam tubuh ternak antara lain mempengaruhi pertumbuhan, reproduksi, pembentukan tulang dan darah, metabolisme asam nukleat, protein dan karbohidrat. Berat telur dipengaruhi oleh beberapa faktor antara lain umur, strain, suhu lingkungan, dan kandungan nutrisi ransum (Bell and Weaver, 2002).

\section{Daya Tetas}

Rataan persentase daya tetas telur puyuh yang diberi pakan tersuplementasi mineral $\mathrm{Zn}$ dan vitamin $\mathrm{E}$ dapat dilihat pada Tabel 6 . penting untuk mencegah kerusakan yang ditimbulkan oleh radikal bebas. Radikal bebas yang meningkat menyebabkan kemampuan pertahanan tubuh berkurang, hal tersebut menjadi pemicu timbulnya stres pada ternak yang berdampak pada penurunan produksi telur dan kualitas telur tetas (Kusumasari dkk, 2013). Stres dapat dicegah dan dikurangi dengan 
Menurut Yuwanta (1993) menyatakan bahwa daya tetas dipengaruhi oleh faktor endogen yaitu kualitas telur, kandungan mikro mineral dan pakan induk, serta faktor eksogen meliputi lama penyimpanan dan kondisi mesin. Ditambahkan oleh Sudjarwo (2001) ada tiga faktor yang mempengaruhi daya tetas yakni telur tetas itu sendiri, mesin tetas, dan operator, masing-masing berperan $33,3 \%$.

Hasil sidik ragam penambahan vitamin $\mathrm{E}$ secara tunggal dalam ransum berpengaruh nyata $(\mathrm{P}<0.05)$ terhadap daya tetas telur puyuh, artinya pemberian vitamin $\mathrm{E}$ dengan dosis $0 \mathrm{mg} / \mathrm{kg}$ pakan, $50 \mathrm{mg} / \mathrm{kg}$ pakan dan $100 \mathrm{mg} / \mathrm{kg}$ pakan dapat mempengaruhi daya tetas telur puyuh. Daya tetas terbaik terlihat pada pemberian vitamin E $45 \mathrm{ppm} / \mathrm{kg}$ pakan sebesar $53 \%$ dibanding dengan pemberian vitamin E $50 \mathrm{ppm} / \mathrm{kg}$ pakan dan tanpa vitamin E masing-masing 38\% dan $24 \%$. Hasil tersebut sejalan dengan pendapat Lubis (2012) menyatakan bahwa untuk kebutuhan burung puyuh yang sedang bertelur, terutama untuk pembibitan, vitamin E yang dibutuhkan adalah sebesar $40 \mathrm{ppm} / \mathrm{kg}$ pakan. Vitamin E selain sebagai antioksidan juga dapat mencegah degenerasi epitel germinalis pada testis, sehingga produksi spermatozoa dan fertilitasnya dapat dipertahankan. Hal tersebut sesuai dengan hasil penelitian Subekti (2005) bahwa suplementasi vitamin E pada ransum menunjukkan peningkatan daya tetas yang signifikan. Namun hasil yang diperoleh tidak sejalan dengan penelitian yang dilaksanakan oleh Maftuh dkk. (2012) bahwa pemberian vitamin $\mathrm{E}$ dengan berbagai tingkatan $(0,5$ IU/ekor/hari, 1 IU/ekor/hari dan 1,5 IU/ekor/hari) tidak berpengaruh terhadap fertilitas, daya tetas dan bobot tetas telur puyuh.

\section{Sex Ratio Anak Puyuh}

Rataan perbandingan jenis kelamin jantan terhadap betina (sex ratio) anak puyuh pada tetua yang diberi pakan tersuplementasi mineral $\mathrm{Zn}$ dan vitamin $\mathrm{E}$ dapat dilihat pada Tabel 7 .

Hasil sidik ragam menunjukkan bahwa interaksi antara mineral seng (Zn) dan vitamin $\mathrm{E}$ tidak berpengaruh $(\mathrm{P}>0.05)$ terhadap sex ratio anak puyuh. Demikian pula dengan perlakuan tunggal mineral seng pada dosis $50 \mathrm{mg} / \mathrm{kg}$ pakan dan dosis $100 \mathrm{mg} / \mathrm{kg}$ maupun vitamin E pada dosis $45 \mathrm{ppm} / \mathrm{kg}$ pakan dan $50 \mathrm{ppm} / \mathrm{kg}$ pakan tidak nyata terhadap persentase $(\%)$ puyuh jantan ( $\mathrm{P}>0.05)$. Hal ini mengindikasikan bahwa pemberian tunggal mineral seng atau vitamin $\mathrm{E}$ maupun kombinasi keduanya ke dalam ransum belum mampu menghambat kerja enzim aromatase, sehingga jumlah puyuh jantan dan betina hampir berimbang. Jenis kelamin unggas dapat berubah, tergantung hormon yang dominan selama perkembangan awal embrio. Fungsi mekanisme genetik pada sistem endokrin embrional mengarahkan differensiasi gonad yang menentukan jenis kelamin embrio (Utomo, 2008).

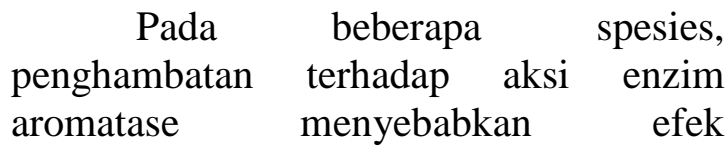
maskulinisasi yang sama dengan efek yang ditimbulkan pada androgen (Liana, 2007). Penurunan rasio estrogen terhadap androgen menyebabkan terjadinya perubahan penampakan dari betina menjadi menyerupai jantan, dengan kata lain terjadi maskulinisasi karakteristik seksual sekunder (Davis et al., 1999 dalam Utomo, 2008). 
Tabel 7. Rataan Prosentase Puyuh Jantan dari Tetua yang Diberi Pakan Tersuplementasi Mineral Zn dan Vitamin E (\%)

\begin{tabular}{lllll}
\hline Perlakuan Pakan & \multicolumn{3}{c}{ Vitamin $(\mathrm{ppm})$} & \multirow{2}{*}{ Rataan } \\
\cline { 2 - 4 } & E0 $(0)$ & E1 (45) & E2 (50) & \\
\hline M0 (Zn 0 mg) & 33.3 & 58.5 & 55.7 & 49.2 \\
M1 (Zn 50 mg) & 72.0 & 61.0 & 53.3 & 62.1 \\
M2 (Zn 100 mg) & 50.0 & 74.3 & 37.7 & 54.0 \\
\hline Rataan & 51.8 & 64.6 & 48.9 & \\
\hline
\end{tabular}

Ket : Superskrip yang berbeda pada baris dan kolom yang sama menunjukkan perbedaan nyata pada taraf $0.05(\mathrm{P}<0.05)$

\begin{abstract}
Mekanisme penghambatan aromatase oleh aromatase inhibitor melalui cara bersaing dengan substrat alami enzim dan selanjutnya berinteraksi dengan sisi aktif dari enzim, mengikatnya dan tidak dapat kembali lagi sehingga mengakibatkan ketidak aktifan dari enzim (Broodie, 1991 dalam Liana, 2012).Selanjutnya Hamzah dkk (2009) berpendapat bahwa semakin tinggi level $\mathrm{Zn}$ berpengaruh menurunkan kadar estradiol dan aktifitas aromatase dan sebaliknya meningkatkan testosterone. Hal ini terjadi karena Zn dapat memblokir aktifitas aromatase sehingga tidak terjadi proses konversi dari testosteron menjadi estradiol.
\end{abstract}

Seperti halnya hormon steroid, efektivitas aromatase inhibitor dalam maskulinisasi juga dipengaruhi oleh dosis, jenis aromatase inhibitor, lama perlakuan, suhu perlakuan dan lama waktu perlakuan (Broodie, 1991).

\section{Kesimpulan}

\section{KESIMPULAN}

a. Suplementasi mineral $\mathrm{Zn} 0 \mathrm{mg} / \mathrm{kg}$ pakan, $50 \mathrm{mg} / \mathrm{kg}$ pakan dan $100 \mathrm{mg} / \mathrm{kg}$ pakan tidak nyata mempengaruhi konsumsi ransum, persentase daya tetas dan ratio anak puyuh jantan dengan anak puyuh betina. b. Suplementasi mineral Zn $100 \mathrm{mg}$ secara mandiri dalam ransum menghasilkan rataan bobot telur tertinggi (10.96 g/butir)

c. Suplementasi vitamin E 45 ppm secara mandiri dalam ransum menghasilkan rataan konsumsi ransum tertinggi (495 g/ekor/minggu)

d. Suplementasi vitamin E 50 ppm secara mandiri dalam ransum menghasilkan rataan bobot telur tertinggi $(10.94 \%)$

e. Suplementasi mineral $\mathrm{Zn} 50 \mathrm{mg}$ dikombinasikan dengan vitamin E 50 ppm dalam ransum menghasilkan rataan bobot telur $11.34 \mathrm{~g}$.

\section{DAFTAR PUSTAKA}

Dian R., L. Affandy, W.C. Pratiwi, P.W. Prihandini. 2009.Pengaruh Pemberian Suplemen Tradisional Terhadap Kualitas Semen Pejantan Sapi Bali. Lembaga Ilmu Pengetahuan Indonesia. Jakarta.

Bell, D. dan Weaver. 2002. Commercial Chicken Meat and Egg. Kluwer Academic Publishers, United States of America. 
Budiyato, A. 2009. Teknologi Penentuan Jenis Kelamin Embrio Tingkatkan Produksi Pangan. Gadjah Mada University Press. Yogyakarta

Broodie A. 1991. Aromatase and its Inhibitors-An Overview. Journal Steroid Biochem. Molec. Biol.40(1):1-3. Dalam: Liana, Y.P. 2007. Efektifitas Aromatase Inhibitor Yang Diberikan Melalui Pakan Buatan Terhadap Sex Reversal Ikan Nila Merah Oreochromis sp. Jurnal Sumberdaya Perairan 1(2):1-7

Davis, R.B., B.A. Simco, C.A. Groudie, N.C. Parker, W. Couldwell, and P.Snellgrove. 1999. Hormonal Sex Manipulation and Evidence for Female Homogamety in Channel Catfish. Gen. Comp. Endocr. 78:219-223. Dalam: Utomo, B. 2008. Efektivitas Penggunaan Aromatase Inhibitor Dan Madu Terhadap Nisbah Kelamin Ikan Gapi (Poecilia reticulata Peters ). Skripsi. Institut Pertanian Bogor. Jawa Barat

Hamzah, M., M.Sobri, D.E, Prasetro. 2009. Evaluasi Perbedaan Level Zn pada Kadar Zn, Estrogen, Progesteron, dan Aromatase Darah, Hati, Telur, dan Ovarium Ayam Petelur. Laporan Akhir Hasil Penelitian Hibah Pascasarjana. Universitas Gadjah Mada

Hanafiah, K.A. 2008. Rancangan Percobaan (Teori dan Aplikasi). Edisi Ketiga. PT Raja Grafindo Perkasa. Jakarta.

Kusumasari. D. P, I. Mangisah, dan I. Estiningdriati. 2013. Pengaruh
Penambahan Vitamin A Dan E Dalam Ransum Terhadap Bobot Telur Dan Mortalitas Embrio Ayam Kedu Hitam. Animal Agriculture Journal, 2(1):191 - 200

Liana, Y.P. 2007. Efektifitas Aromatase Inhibitor Yang Diberikan Melalui Pakan Buatan Terhadap Sex Reversal Ikan Nila Merah Oreochromis sp. Jurnal Sumberdaya Perairan 1(2):1-7

Lubis, F.N.L, 2012. Suplementasi Selenium Organik dan Vitamin E dalam Pakan Induk Terhadap Performa Anak Puyuh. Jurnal Peternakan Sriwijaya, 1(1):65-74

Maftuh N, E. Sujarwo, I.H Djunaidi. 2012. Pengaruh Pemberian Vitamin E Terhadap Nilai Fertilitas, Daya Tetas, Dan Bobot Tetas Telur Burung Puyuh. Universitas Brawijaya.

Mahi M, Achmanu, dan Muharlien. 2012. Pengaruh Bentuk Telur Dan Bobot Telur Terhadap Jenis Kelamin, Bobot Tetas Dan Lama Tetas Burung Puyuh (Coturnix-coturnix Japonica). Universitas Brawijaya.

North, M.O. dan D. D. Bell. 1999. Commercial Chicken Production Manual. $4^{\text {th }}$ Ed. Van Nostrand Reinhold. New York

Sahin, K., O. Kucuk, N. Sahin, and M.F. Gursu. 2002. Optimal Dietary Concentration of Vitamin $E$ for Alleviating the Effect of Heat Stress on Performance, Thyroid Status, ACTH and Some Serum Metabolite and Mineral Concentration in 
Broiler. Vet. Med.-Czech, 47 : 110116.

Sestilawarti. 2011. Pengaruh Pemberian Mikrokapsul Minyak Ikan dalam Ransum Puyuh terhadap Performa Produksi dan Kualitas Telur. Artikel Program Pasca Sarjana. Universitas Andalas, Padang.

Suharyati, S. 2006. Pengaruh Penambahan Vitamin E Dan Mineral Zn Terhadap Kualitas Semen Serta FertilitasDan Daya Tetas Telur Kalkun Lokal. J.Indo.Trop.Anim.Agric，31(3):179183

Suharyati, S dan M. Hartono. 2013. Peningkatan Kualitas Semen Kambing Boer Dengan Pemberian Vitamin E dan Mineral Zn. Jurnal Kedokteran Hewan, 7(2):70-75

Subekti, E. 2005. Pengaruh Kombinasi Suplementasi Vitamin $C$ dan Vitamin $E$ Sintetis Terhadap Produksi dan Daya Tetas Telur Puyuh. Mediagro, I(2); 45-57.
Surai PF. 2003. Natural Antioxidants In Avian Nutrition and Reproduction. Nottingham UK. Nottingham University Press.

Utomo, B. 2008. Efektivitas Penggunaan Aromatase Inhibitor Dan Madu Terhadap Nisbah Kelamin Ikan Gapi (Poecilia reticulata Peters ). Skripsi. Institut Pertanian Bogor. Jawa Barat

Vaillant S, M. Dorizzi, C. Pieau, and N. Richard-Mercier 2001. Sex Reversal and Aromatase In Chicken. Journal Of Experimental Zoology 290:727-740.

Wijayanti, D.R. 2012. Pengaruh Aromatase Inhibitor Terhadap Nisbah Kelamin Ikan Nilem Hasil Ginogenesis. (8 Januari 2015)

Yunilas, Z Siregar dan N.S Wenthy. 2007. Pengaruh suplementasi mineral $(\mathrm{Na}, \mathrm{Ca}, \mathrm{P}, \mathrm{Cl})$ dalam ransum terhadap produksi telur puyuh (Cortunix-cortunix japonica). Jurnal Agribisnis Peternakan FP USU. Medan, 3(2);61-65. 